\title{
Políticas públicas na área da saúde: notas sobre o planejamento prévio à celebração de contratos de gestão com organizações sociais
}

Public health policies: notes about planning prior to management contracts with social organizations

\section{Fabrício Macedo Motta ${ }^{1}$ \\ Fernanda de Moura Ribeiro Naves ${ }^{2}$}

Resumo: As parcerias com organizações sociais,
previstas na Lei Federal $n^{\circ} 9.637 / 1998$ e regidas
por contratos de gestão, objetivam oferecer uma
alternativa à eficiência, agilidade e flexibilidade na
assistência à saúde. Na fase de decisão de publiciza-
ção, a Administração Pública deve realizar estudos
técnicos e jurídicos acerca das vantagens da parceria,

1 Vice Coordenador do Programa de Pós-Graduação em Direito e Políticas Públicas (UFG). Doutor em Direito do Estado (USP) e Mestre em Direito Administrativo (UFMG). Conselheiro do Tribunal de Contas dos Municípios do Estado de Goiás (TCM/GO). A participação neste artigo é fruto de pesquisa desenvolvida com apoio institucional do PPGDP-UFG e seus financiadores.

2 Mestre em Direito e Políticas Públicas (UFG). Especialista em Direito Processual Civil (UFG). Especialista em Direito Público (Faculdade Fortium). Especialista em Auditoria em Controle Externo (Faculdade Fortium). MBA em Gestão Pública (Universidade Anhanguera Educacional/LFG). Auditora de Controle Externo da Área Jurídica do Tribunal de Contas dos Municípios do Estado de Goiás (TCM/GO). 
com definição motivada acerca do objeto da avença. $\mathrm{O}$ artigo aborda a etapa do planejamento prévio à celebração de contratos de gestão, tratando da adoção de metodologias voltadas à verificação da eficiência do ajuste. Contratos de gestão são abordados em sua qualidade de instrumentos de políticas públicas na área da saúde, e o planejamento enfocado como dever do gestor público.

Palavras-chave: Organizações sociais. Saúde. Planejamento. Políticas públicas. Value for Money.

Abstract: Partnerships with social organizations, provided for in Federal Law $n^{0} 9.637 / 1998$ and governed by Management Contracts, aim to offer an alternative to efficiency, agility, and flexibility in health care. In the publicization decision phase, the Public Administration must carry out technical and legal studies about the partnership's benefits, with a motivated definition about the object of the agreement. In this context, the public manager must value the planning stage of these contracts with the adoption of his own methodologies, as eventual failures in this phase may cause inexplicable results or even a huge waste of public money. The provision of services by social organizations is only justified when it has proven to be more economical than direct execution.

Keywords: Public policies. Health. Planning. Publicization decision. Value for Money

Sumário: 1. Introdução. 2. Organizações sociais e contratos de gestão na área da saúde. 3. Contratos de gestão como instrumentos de políticas públicas de saúde. 4. Planejamento: etapa prévia necessária à celebração de contratos de gestão com organizações sociais para prestação de serviços de saúde - 5. Instrumentos 
para aferição do ganho de eficiência na contratação e serviços públicos de saúde: Value for Money (VfM) e valor público. Conclusão.

\section{Introdução}

Este artigo tem como tema central a etapa de planejamento da transferência de serviços de saúde para organizações sociais. A Lei Federal no 9.637, de 15 de maio de 1.998, previu a possibilidade de descentralização da execução de serviços públicos para entidade privada sem fins lucrativos qualificada como organização social (OS), por meio da pactuação de contrato de gestão ${ }^{3}$. As organizações sociais tiveram seus contornos jurídico-normativos estabelecidos na década de 1990, no Plano Diretor da Reforma do Estado, elaborado pelo então ministro Luiz Carlos Bresser Pereira. O plano desenvolveu a ideia chamada de "publicização", consistente no incentivo a entidades privadas de interesse público e transformação de fundações públicas em entidades de direito privado, sem fins lucrativos, para colaborarem na execução de serviços públicos não privativos do Estado.

O Supremo Tribunal Federal ${ }^{4}$, no julgamento da ADI $1.923^{5}$, proclamou a constitucionalidade da celebração de

3 O art. $1^{\circ}$ da Lei $n^{\circ}$ 9.637/1.998 dispõe que: “O Poder Executivo poderá qualificar como organizações sociais pessoas jurídicas de direito privado, sem fins lucrativos, cujas atividades sejam dirigidas ao ensino, à pesquisa científica, ao desenvolvimento tecnológico, à proteção e preservação do meio ambiente, à cultura e à saúde, atendidos aos requisitos previstos nesta lei."

4 Disponível em: http://portal.stf.jus.br/processos/downloadPeca. asp?id=308380793\&ext=.pdf. Acesso em: 11 nov. 2019.

5 Em voto-vista, o Min. Gilmar Mendes, sustentou que a Lei nº 9.637/1998 institui um programa de publicização de atividades e serviços não exclusivos do Estado, transferindo-os para a gestão desburocratizada a cargo de entidades de caráter privado e, portanto, submetendo-os a um regime mais flexível, dinâmico e eficiente. Ressaltou que a busca da 
contratos de gestão com organizações sociais no âmbito do Sistema Único de Saúde (SUS), conforme previsão expressa nos artigos $197^{6}$ e 199, §1 ${ }^{07}$, da Constituição Federal, desde que a pactuação contratual seja conduzida de forma pública, objetiva e impessoal, em obediência aos princípios constitucionais que regem a Administração Pública previstos no caput do art. 37.

A afirmação da constitucionalidade do contrato de gestão pelo Supremo Tribunal Federal não resolveu todas as complexas questões ligadas ao regime jurídico do vínculo das organizações sociais com o Estado.

O problema central do artigo pode ser resumido na seguinte indagação: o planejamento prévio é etapa imposta pelo ordenamento como elemento vinculante da decisão jurídico-administrativa relativa à celebração de contratos de gestão com organizações sociais, para a prestação de serviços complementares na área da saúde? A hipótese formulada é que o ordenamento jurídico exige o planejamento prévio em razão do interesse público envolvido, fundado especialmente no desenho jurídico-normativo dos contratos de gestão como instrumentos voltados ao incremento da economicidade de eficácia na prestação de serviços públicos. Desta forma, no que

eficiência dos resultados, mediante a flexibilização de procedimentos justifica a implementação de um regime especial, regido por regras que respondem a racionalidades próprias do direito púbico e do direito privado.

6 Art. 197. São de relevância pública as ações e serviços de saúde, cabendo ao Poder Público dispor, nos termos da lei, sobre sua regulamentação, fiscalização e controle, devendo sua execução ser feita diretamente ou através de terceiros e, também, por pessoa física ou jurídica de direito privado.

7 Art. 199. A assistência à saúde é livre à iniciativa privada.

$\S 1^{\circ}$ As instituições privadas poderão participar de forma complementar do sistema único de saúde, segundo diretrizes deste, mediante contrato de direito público ou convênio, tendo preferência as entidades filantrópicas e as sem fins lucrativos. 
diz respeito à etapa preparatória para a celebração do ajuste ${ }^{8}$, é necessário anotar que a desnecessidade de realização de processo licitatório não exime a Administração Pública de demonstrar as razões de interesse público que indicam a opção pela publicização dos serviços, especialmente dos serviços de saúde. Essas razões, no regime geral licitatório, como regra, se traduzem em demonstrações de economicidade: é imprescindível demonstrar que a opção administrativa por determinado modelo de contração e gestão trará maior economicidade do que outras alternativas. Em se tratando de contratações colaborativas, celebradas com entes sem finalidades econômicas, contudo, o cenário se torna mais complexo: como referido, as nuances específicas do interesse público podem envolver não somente economicidade como também ganhos de eficiência ou mesmo externalidades outras ligadas ao impacto nos direitos fundamentais e no alcance dos objetivos da República.

A metodologia utilizada envolve pesquisa bibliográfica e cotejo com decisões recentes do Supremo Tribunal Federal e Tribunal de Contas da União, as primeiras (STF) analisadas com o intuito de identificar as características do regime jurídico aplicável (em razão da dos efeitos próprios das ações de controle de constitucionalidade) e as demais enfocadas para compreender irregularidades específicas verificadas nas fiscalizações realizadas pelo TCU. O estudo parte do pressuposto de que a celebração do contrato de gestão é o ponto final de uma etapa procedimental, composta por diversas sub-etapas juridicamente reguladas com maior ou menor intensidade, ligada à avaliação e decisão motivada envolvendo alternativas de gestão pública, que deve ser pautada em metodologia adequada para aferição do ganho

8 Tal etapa, no regime jurídico estabelecido pela Lei no 8.666/93, é comumente conhecida como "fase interna da licitação". 
de eficiência na contratação desses serviços, a exemplo do Value for Money (VfM). Este estudo também considera o contrato de gestão como ferramenta jurídico-administrativa utilizada no contexto de políticas públicas de saúde. Desta forma, caracterizaremos políticas públicas como arranjos complexos que podem conter arranjos contratuais variados, mas que não se limitam a eles.

\section{Organizações sociais e contratos de gestão na área da saúde}

O Plano Diretor da Reforma do Estado foi o principal instrumento do movimento de Reforma do Estado, divulgado e implementado no final dos anos 1990. Ao classificar os campos de atuação do Estado, o Plano identificava a existência de um setor de serviços não exclusivos, correspondente a segmento contendo atividades relevantes nas quais o Estado atuaria sem prerrogativas de autoridade, simultaneamente com outras organizações públicas não-estatais e privadas. $\mathrm{O}$ modelo jurídico das organizações sociais foi um dos pilares do Plano Diretor da Reforma do Aparelho do Estado. De acordo com o Plano:

Organizações Sociais (OS) são um modelo de organização pública não-estatal destinado a absorver atividades publicizáveis mediante qualificação específica. Trata-se de uma forma de propriedade pública não-estatal, constituída pelas associações civis sem fins lucrativos, que não são propriedade de nenhum indivíduo ou grupo e estão orientadas diretamente para o atendimento do interesse público. As OS são um modelo de parceria entre o Estado e a sociedade. O Estado continuará a fomentar as atividades publicizadas e exercerá sobre elas um controle estratégico: demandará resultados necessários ao atingimento dos objetivos das políticas públicas. $\mathrm{O}$ contrato de gestão é o instrumento que regulará as ações das OS. As Organizações Sociais constituem uma inovação institucional, 
embora não representem uma nova figura jurídica, inserindo-se no marco legal vigente sob a forma de associações civis sem fins lucrativos. Estarão, portanto, fora da Administração Pública, como pessoas jurídicas de direito privado. A novidade será, de fato, a sua qualificação, mediante decreto, como Organização Social, em cada caso. Qualificada como Organização Social, a entidade estará habilitada a receber recursos financeiros e a administrar bens e equipamentos do Estado. Em contrapartida, ela se obrigará a celebrar um contrato de gestão, por meio do qual serão acordadas metas de desempenho que assegurem a qualidade e a efetividade dos serviços prestados ao público ${ }^{9}$.

No planejamento inicial, a implementação das organizações sociais - ou OS's, como poderão ser referidas doravante - implicava a extinção de entidades estatais e a absorção de suas atividades por entidades privadas qualificadas, mediante celebração de contrato de gestão. A Lei n ${ }^{0} 9.637$, de 15 de maio de 1998, criou no âmbito da União um novo título jurídico - organização social - extinguiu o Laboratório Nacional de Luz Síncrotron, integrante da estrutura do Conselho Nacional de Desenvolvimento Científico e Tecnológico - CNPq, e a Fundação Roquette Pinto, entidade vinculada à Presidência da República, e ainda autorizou a qualificação de duas entidades como Organizações Sociais para a assunção dos respectivos serviços. Desta forma, o instrumento jurídico essencial para o desenvolvimento de atividades colaborativas entre Estado e particulares, nas áreas relacionadas na referida Lei Federal, é o contrato de gestão, assim entendido como "o instrumento firmado entre o Poder Público e a entidade qualificada como organização social, com vistas à formação de parceria entre as partes para fomento e execução de atividades relativas às áreas relacio-

9 BRASIL. Ministério da Administração Federal e Reforma do Estado / Secretaria da Reforma do Estado Organizações sociais. / Secretaria da Reforma do Estado. Brasília: Ministério da Administração e Reforma do Estado, 1997. 74 p. (Cadernos MARE da reforma do estado; v. 2). 
nadas no art. $1^{\circ \prime \prime}$ (art.5 $5^{\circ}$ da Lei $\left.n^{\circ} 9.637 / 98\right)$. Convém anotar que o modelo criado pela Lei Federal no 9.637/98, aplicável apenas à União, serviu de inspiração para a edição de leis estaduais e municipais disciplinando contratos de gestão no âmbito dos respectivos entes federativos.

Na doutrina de Fernando Borges Mânica ${ }^{10}$ o contrato de gestão é:

[...] modalidade de parceria por meio da qual o Poder Público repassa recursos financeiros, físicos e humanos a uma entidade privada qualificada como organização social, que assume a gestão de uma estrutura pública voltada à prestação de serviços públicos sociais ou serviços de interesse público, com o objetivo de alcançar padrões de eficiência e qualidade previamente definidos no instrumento de ajuste. O contrato de gestão é disciplinado pela Lei federal $n^{\circ} 9.637$, de 15 de maio de 1998, e também por leis estaduais e municipais que regulamentam o tema em cada esfera federativa.

O modelo desenhado na esfera federal se espalhou, em maior ou menor amplitude, para diversos estados da federação. Esse processo ocorreu por meio da edição de leis próprias de cada um dos entes, considerando-se que a Lei $n^{\circ} 9.637 / 98$ seria norma federal, e não norma geral. A despeito de pesquisas específicas, a experiência profissional indica que a saúde tem sido, largo modo, a área preferencial de atuação das organizações sociais. A esse respeito, o art. 197 da Constituição Federal estabelece que a execução das ações e serviços de saúde se dará através do Poder Público diretamente ou através de terceiros, por pessoa física ou jurídica de direito privado. De acordo com a Constituição, a prestação de saúde é, de forma primária, responsabilidade estatal, e a iniciativa privada possui caráter meramente complementar à atividade do Estado, e com observância das diretrizes próprias do Sistema Único de Saúde (SUS).

10 MÂNICA, 2017, p.131. 
Especificamente em relação aos serviços públicos de saúde, a Lei no 8.080/90 (Lei Orgânica da Saúde) traz o seguinte regramento em relação à complementaridade do SUS:

Art. 24 Quando as suas disponibilidades forem insuficientes para garantir a cobertura assistencial à população de uma determinada área, o Sistema Único de Saúde (SUS) poderá recorrer aos serviços ofertados pela iniciativa privada.

Parágrafo único. A participação complementar dos serviços privados será formalizada mediante contrato ou convênio, observadas, a respeito, as normas de direito público.

Art. 25. Na hipótese do artigo anterior, as entidades filantrópicas e as sem fins lucrativos terão preferência para participar do Sistema Único de Saúde (SUS).

Art. 26. Os critérios e valores para a remuneração de serviços e os parâmetros de cobertura assistencial serão estabelecidos pela direção nacional do Sistema Único de Saúde (SUS), aprovados no Conselho Nacional de Saúde.

$\S 1^{\circ} \mathrm{Na}$ fixação dos critérios, valores, formas de reajuste e de pagamento da remuneração aludida neste artigo, a direção nacional do Sistema Único de Saúde (SUS) deverá fundamentar seu ato em demonstrativo econômico-financeiro que garanta a efetiva qualidade de execução dos serviços contratados.

$\S 2^{\circ}$ Os serviços contratados submeter-se-ão às normas técnicas e administrativas e aos princípios e diretrizes do Sistema Único de Saúde (SUS), mantido o equilíbrio econômico e financeiro do contrato.

$\S 3^{\circ}$ (Vetado).

$\S 4^{\circ}$ Aos proprietários, administradores e dirigentes de entidades ou serviços contratados é vedado exercer cargo de chefia ou função de confiança no Sistema Único de Saúde (SUS). (Grifamos)

O que imprecisamente costuma ser referenciado como terceirização no SUS contempla situações legalmente previstas na Lei $n^{\circ} 8.080 / 1990$, formalizadas mediante ajustes contratuais variados (contratos, em sentido amplo, e convênios), com observância das regras de contratação pública. A Lei ${ }^{\circ}$ $9.637 / 1998$, por sua vez, prevê que algumas atividades de caráter social, exercidas por pessoas e órgãos administrativos 
de direito público, podem ser absorvidas por pessoas de direito privado, ocorrendo a substituição integral do público pelo atuar privado suprido por recursos públicos. Desta forma, como anota Fernando Mânica ${ }^{11}$, o gestor público pode recorrer aos serviços prestados pela iniciativa privada quando as suas disponibilidades forem insuficientes para garantir a cobertura assistencial à população de determinada área.

Percebe-se que a atuação do particular nas atividades complementares ligadas à saúde pública encontra-se em área jurídica cinzenta que tangencia os clássicos conceitos de público e privado. Em razão dessa imbricação necessária entre público e privado foi interposta a Ação Direta de Inconstitucionalidade $\mathrm{n}^{\circ} 1.923 / \mathrm{DF}$, cujo julgamento determinou os principais matizes do regime jurídico do contrato de gestão.

Em 1998 foi proposta no Supremo Tribunal Federal a Ação Direta de Inconstitucionalidade ${ }^{\circ}$ 1923-DF, questionando diversos dispositivos da Lei $\mathrm{n}^{\circ} 9.637 / 98$ e também o inc. XXIV do art. 24 da Lei Federal ${ }^{0}$ 8.666/93, incluído pela Lei $n^{\circ} 9.648 / 98$ (esse último dispositivo permitiu nova hipótese modalidade de dispensa de licitação para a celebração de contratos de prestação de serviços com as Organizações Sociais).

O julgamento da ADI foi concluído em 16 de abril de 2015, tendo sido o acórdão respectivo publicado em 17 de dezembro do mesmo ano, assentando a juridicidade do modelo de Organizações Sociais instituído pela Lei n ${ }^{\circ}$ 9.637/98. O voto condutor do Acórdão, da lavra do Ministro Luiz Fux, aduz que nos limites constitucionalmente assegurados, as maiorias políticas prevalecentes no jogo democrático pluralista podem colocar em prática seus projetos de governo, moldando o perfil e o instrumental do poder público conforme a vontade coletiva. Os setores de saúde (CF, art. 199,

11 MÂNICA, 2017, p.116. 
caput), educação (CF, art. 209, caput), cultura (CF, art. 215), desporto e lazer (CF, art. 217), ciência e tecnologia (CF, art. 218) e meio ambiente (CF, art. 225) configuram serviços públicos sociais, em relação aos quais a Constituição permite a atuação, por direito próprio, dos particulares, sem que para tanto seja necessária a delegação pelo poder público, de forma que não incide o art.175, caput, da Constituição. Ao considerar a existência de serviços públicos sociais, em síntese, o STF asseverou que os particulares podem atuar por direito próprio e que a celebração de contratos de gestão não caracteriza qualquer forma de renúncia aos deveres constitucionais de atuação estatal.

Dentre as razões condutoras do voto destaca-se o entendimento de que o modelo de Organizações Sociais se caracteriza como intervenção indireta no domínio social e econômico, constituindo nítida atividade de fomento público no domínio dos serviços sociais. A finalidade de fomento é operacionalizada por meio da cessão de recursos, bens e pessoal da Administração Pública para as entidades privadas, após a celebração de contrato de gestão, o que viabilizará o direcionamento, pelo Poder Público, da atuação do particular em consonância com o interesse público, através da inserção de metas e de resultados a serem alcançados, sem que isso configure qualquer forma de renúncia aos deveres constitucionais de atuação. Sob esse enfoque, o contato de gestão a parece como um dos instrumentos para a realização de políticas públicas nas áreas antes delimitadas, sendo que a Lei n ${ }^{\circ}$ 9.637/98 dá contornos para a decisão política de afastar a atuação de entidades públicas através da intervenção direta para privilegiar a escolha pela busca dos mesmos fins através da indução e do fomento de atores privados.

Destacamos a decisão final proferida pelo Supremo Tribunal Federal: 
Ação direta de inconstitucionalidade cujo pedido é julgado parcialmente procedente, para conferir interpretação conforme à fixados em abstrato segundo o que prega o art. 20 da Lei $n^{\circ}$ 9.637/98; (ii) a celebração do contrato de gestão seja conduzida de forma pública, objetiva e impessoal, com observância dos princípios do caput do art. 37 da CF; (iii) as hipóteses de dispensa de licitação para contratações (Lei no 8.666/93, art. 24, XXIV) e outorga de permissão de uso de bem público (Lei n ${ }^{\circ}$ 9.637/98, art. $12, \$ 3^{\circ}$ ) sejam conduzidas de forma pública, objetiva e impessoal, com observância dos princípios do caput do art. 37 da CF; (iv) os contratos a serem celebrados pela Organização Social com terceiros, com recursos públicos, sejam conduzidos de forma pública, objetiva e impessoal, com observância dos princípios do caput do art. 37 da $\mathrm{CF}$, e nos termos do regulamento próprio a ser editado por cada entidade; (v) a seleção de pessoal pelas Organizações Sociais seja conduzida de forma pública, objetiva e impessoal, com observância dos princípios do caput do art. 37 da $\mathrm{CF}$, e nos termos do regulamento próprio a ser editado por cada entidade; e (vi) para afastar qualquer interpretação que restrinja o controle, pelo Ministério Público e pelo TCU, da aplicação de verbas públicas Constituição à Lei no 9.637/98 e ao art. 24, XXIV, da Lei $n^{\circ} 8666 / 93$, incluído pela Lei $n^{\circ} 9.648 / 98$, para que: (i) o procedimento de qualificação seja conduzido de forma pública, objetiva e impessoal, com observância dos princípios do caput do art. 37 da CF, e de acordo com parâmetros fixados em abstrato segundo o que prega o art. 20 da Lei n ${ }^{\circ}$ 9.637/98; (ii) a celebração do contrato de gestão seja conduzida de forma pública, objetiva e impessoal, com observância dos princípios do caput do art. 37 da CF; (iii) as hipóteses de dispensa de licitação para contratações (Lei $\mathrm{n}^{\circ}$ 8.666/93, art. 24, XXIV) e outorga de permissão de uso de bem público (Lei $n^{\circ} 9.637 / 98$, art. $12, \$ 3^{\circ}$ ) sejam conduzidas de forma pública, objetiva e impessoal, com observância dos princípios do caput do art. 37 da CF; (iv) os contratos a serem celebrados pela Organização Social com terceiros, com recursos públicos, sejam conduzidos de forma pública, objetiva e impessoal, com observância dos princípios do caput do art. 37 da $\mathrm{CF}$, e nos termos do regulamento próprio a ser editado por cada entidade; (v) a seleção de pessoal pelas Organizações Sociais seja conduzida de forma pública, objetiva e impessoal, com observância dos princípios do caput do art. 37 da $\mathrm{CF}$, e nos termos do regulamento próprio a 
ser editado por cada entidade; e (vi) para afastar qualquer interpretação que restrinja o controle, pelo Ministério Público e pelo TCU, da aplicação de verbas públicas.

Os contratos de gestão são considerados ajustes de natureza colaborativa - convênios, em sentido amplo ${ }^{12}$. Por essa razão, as normas da Lei n ${ }^{0}$ 8.666/93 lhes são aplicáveis apenas no que couber, nos termos do artigo 116 13 : os dispositivos da Lei de Licitações não são aplicáveis automaticamente, in totum, mas apenas no que não contrariar a natureza e as finalidades do referido contrato, nos termos da legislação específica. Nesse particular, são esclarecedoras algumas conclusões de Rafael Arruda Oliveira:

[...] IV - Ajustes de natureza colaborativa, os quais têm por base o fomento público, não se confundem com os contratos de prestação de serviços administrativos, cuja disciplina normativa é estabelecida pela Lei Federal ${ }^{\circ} 8.666 / 93$, e que, por conseguinte, é imprópria para reger relação mantida pelo Poder Público com parceiros;

V - a realização de procedimento licitatório, nos termos da Lei Geral de Licitações, para a seleção da entidade privada que, por meio de fomento público, estabelecerá vínculo de parceria com a Administração, mostra-se inapropriada, já que aquela legislação, a despeito de uma pretensa uniformidade que se quer conferir a todas as espécies de "contratos", não se aplica, à evidência, a todos os ajustes que o Poder Público celebra;

VI - a regência da disciplina acerca da seleção de parceiros deve ocorrer por meio de regime jurídico-administrativo específico, cabendo aos entes políticos, por meio de atos normativos próprios, estabelecer o procedimento público, objetivo e imparcial para a

12 A esse respeito, vide: MOTTA, FABRÍCIO. Organizações sociais e a Lei ${ }^{\circ}$ 13.019/14. In: MOTTA, Fabrício; MÂNICA, Fernando Borges; OLIVEIRA, Rafael Arruda. (Org.). Parcerias com o terceiro setor: as inovações da Lei $\mathbf{n}^{\mathbf{0}}$ 13.019/14. 2ed.Belo Horizonte: Fórum, 2018, p. 157-179.

13 Art. 116. Aplicam-se as disposições desta Lei, no que couber, aos convênios, acordos, ajustes e outros instrumentos congêneres celebrados por órgãos e entidades da Administração. 
escolha da entidade privada filantrópica que melhor atenda às exigências da Administração;

VII - a limitação temporal expressa no inciso II do art. 57 da Lei Federal $n^{\circ} 8.666 / 93$ revela-se inadequada para a disciplina de ajustes de natureza convenial, já que as entidades privadas filantrópicas, designadamente as organizações sociais, como parceiras do ente estatal no desempenho de uma atividade de relevância social, não são, na forma da Lei Geral de Licitações, prestadoras de serviço administrativo comum a ser executado de forma contínua (contrato administrativo comum);

VIII - os entes políticos, no exercício de sua autonomia legislativa para dispor sobre fomento público, podem disciplinar o tempo máximo de vigência de contratos de gestão, incluídas eventuais prorrogações, ou mesmo indicar que a determinação do prazo do ajuste haverá de se dar contratualmente, a exemplo do que sucede na Lei Federal no 8.987/95;

IX - A lógica convenial extraída da celebração de ajustes de parceria do Poder Público com o setor privado afasta a incidência do $\S 1^{\circ}$ do art. 65 da Lei Geral de Licitações, quando estabelece o plafond de $25 \%$ do valor inicial atualizado do contrato em matéria de acréscimos ou supressões relativos a obras, serviços ou compras, tendo em vista o alcance de finalidades supraeconômicas ${ }^{14}$.

Finalmente, a despeito da Lei 9.637/1998 e do Decreto 9.190/2017, aplicáveis na esfera federal, a decisão proferida na ADI 1.923/DF, parcialmente transcrita, e a jurisprudência do Tribunal de Contas da União (particularmente manifestada por intermédio do Acórdão TC 023.410/2016-7 - Plenário ${ }^{15}$ e Acórdão 3239/2013-TCU-Plenário ${ }^{16}$ ), são os atos

14 OLIVEIRA, 2013. Conclusões semelhantes constam de resposta a consulta realizada pelo Tribunal de Contas dos Municípios do Estado de Goiás (Acórdão AC-CON nº 0009/13, Rel. Cons. Vasco Jambo, Tribunal Pleno, Julgamento em 22/05/13).

15 O Acórdão é decorrente de consulta formulada pelo Congresso Nacional, no qual se fixa a possibilidade de celebração de Contratos de Gestão em Saúde, e é feito um apanhado geral das decisões mais relevantes do Tribunal de Contas da União até então.

16 O Acórdão se refere a auditoria realizada para examinar em que medida os entes governamentais estavam exercendo as funções de supervisão de 
que atualmente conferem os principais contornos jurídicos do modelo contrato de gestão celebrado no setor de saúde ${ }^{17}$.

\section{Contratos de gestão como instrumentos de políticas públicas de saúde}

Como dito no tópico precedente, no acórdão que concluiu o julgamento da ADI 1923 é possível perceber que a celebração de contratos de gestão com organizações sociais pode ser encarada como política pública de fomento a tais instituições, de forma necessariamente integrada a políticas públicas voltadas à prestação dos serviços públicos sociais, como a saúde. Maria Paula Dallari Bucci enfoca as políticas públicas em seu caráter dinâmico, caracterizando-as como direito em ação:

Política pública é o programa de ação governamental que resulta de um processo ou conjunto de processos juridicamente regulados - processo eleitoral, processo de planejamento, processo de governo, processo orçamentário, processo legislativo, processo administrativo, processo judicial - visando coordenar os meios à disposição do Estado e as atividades privadas para a realização de objetivos socialmente relevantes e politicamente determinados. Como tipo ideal, a política pública deve visar a realização de objetivos definidos, expressando a seleção de prioridades, a reserva

forma efetiva em relação às Organizações Sociais, sendo fiscalizadas as Secretarias Estaduais de Saúde da Bahia, da Paraíba e de São Paulo, e as Secretarias de Saúde dos Municípios de Araucária, Curitiba, Rio de Janeiro, Salvador e São Paulo. Muitas das irregularidades então apontadas (2013) permanecem recorrentes no material de referência atual, especialmente em face de casos na esfera municipal.

17 Sobre a contabilização de despesas com pessoal, que não é objeto deste artigo, também são relevantes os Acórdãos n 2.444/2016 e nº 1.187/2019 Plenário, no qual o TCU mudou de direção e indicou que as despesas de pessoal decorrentes de contratos de gestão das atividades absorvidas por entidade privada deverão ser incluídas no cômputo total para verificação dos limites de gastos com pessoal da União. 
de meios necessários à sua consecução e o intervalo de tempo em que se espera o atingimento dos resultados ${ }^{18}$.

Trata-se, enfim, de ações governamentais processualmente estruturadas e juridicamente reguladas, em diversos níveis, com o envolvimento de diversos atores e instituições, por meio da utilização de variados métodos e estratégias. No que se refere ao enfoque jurídico, convém destacar que o tema ganhou novo e decisivo realce com o advento e desenvolvimento do Estado Social, notadamente em razão de sua importância para a plena eficácia dos direitos fundamentais sociais. Em abordagem jurídico-institucional, a mesma autora considera possível alargar o alcance das políticas públicas para que possam ser compreendidas de forma integrada com o contexto político-institucional em que operam, sem abstrair do fundamental papel desempenhado pelo direito e pelo jurista.

A concretização dos direitos sociais é condição propícia para o robustecimento da abordagem de direito e políticas públicas que, entretanto, com ela (a concretização) não se confunde, e nem a ela se resume. A abordagem tem como objeto de interesse principal os diversos meios de organização para o atingimento de fins, ambos estabelecidos em diferentes graus de juridicidade, por entender que:

[...] no campo das políticas públicas, não é indiferente ou aleatória para o Estado a escolha dos caminhos e arranjos adotados para a concretização da decisão política. Ao contrário: trata-se do resultado de um esforço intencional e consciente no qual normas, processos, atores e instituições jurídicas desempenham um papel mais relevante do que, à primeira vista, pode parecer, inclusive aos olhos dos próprios juristas ${ }^{19}$.

18 BUCCI, 2006, pp. 1-50.

19 BUCCI e COUTINHO, 2017. Os autores identificam as funções do direito nas políticas públicas: “Em primeiro lugar, embora uma política pública 
Em recorte bem mais restrito, políticas públicas podem ser encaradas como conjunto de processos juridicamente regulados voltados ao desempenho de atividades normativamente atribuídas à Administração Pública. Nessa acepção objetiva, a expressão Administração Pública abrange o exercício das múltiplas atividades que compõem a função administrativa estatal, na forma como estruturada no ordenamento, sendo o fomento a atividade que abrange os instrumentos e técnicas de que se vale a Administração, que estimula as atividades econômicas e sociais da iniciativa privada para atingir objetivos ligados ao interesse público. Desta forma, a celebração de contratos de gestão aparece como um dos instrumentos disponíveis para o fomento de entidades da sociedade civil que se enquadrem no modelo de organizações sociais e abrangendo, ao mesmo tempo, a prestação de serviços públicos de saúde.

O Estado, desta forma, se vale de políticas públicas como instrumentos para o exercício de suas variadas atribuições (integrantes do conjunto que se conhece como administração pública em sentido objetivo). Políticas públicas, nesse recorte, aparecem como meio, método ou ferramenta de organização e estruturação para alcance de determinados fins. A abordagem desses diversos processos e meios de organização, juridicamente regulados em maior ou menor

não se confunda com o aparato jurídico que a estrutura, compreender os papéis do direito nas políticas públicas não é uma tarefa simples. O direito está nelas amalgamado e pode cumprir distintas funções: i) determinar normativamente os objetivos a serem perseguidos; ii) apontar, mesmo que de forma ampla, os instrumentos a serem utilizados para alcançálos; iii) criar canais de participação social e legitimação democrática e iv) estruturar arranjos institucionais voltados à coordenação de processos e à atribuição de tarefas e responsabilidades aos agentes em tais políticas envolvidos.5 Por isso, além de dar forma e norte às políticas públicas, o direito também é delas constitutivo e central em seu funcionamento, avaliação, aperfeiçoamento e substituição" (Id.). 
intensidade, costuma ser feita por meio da metodologia do ciclo de políticas públicas. Klaus Frey disseca as grandes etapas de formulação, implementação e controle nas seguintes fases: percepção e definição de problemas, agenda-setting, elaboração de programas e decisão, implementação de políticas e, finalmente, a avaliação de políticas e a eventual correção da ação ${ }^{20}$.

No ciclo proposto, a fase de elaboração de programas e decisão implica em identificar e escolher alternativas, avaliando opções e estratégias, após a introdução do problema na pauta da Administração Pública. Desta forma, no cumprimento do imperativo constitucional segundo o qual "a saúde é direito de todos e dever do Estado" (art.196), cabe ao Estado-Administração planejar e motivadamente decidir entre as diversas alternativas de políticas públicas sociais e econômicas "que visem à redução do risco de doença e de outros agravos e ao acesso universal e igualitário às ações e serviços para sua promoção, proteção e recuperação". O fomento às organizações sociais, por intermédio de arranjos contratuais colaborativos (contratos de gestão) são então considerados e inseridos como elementos, partes integrantes, de determinada política pública.

Arranjos contratuais variados, desta forma, aparecem como ferramentas ou estratégias juridicamente reguladas, utilizadas para a consecução das finalidades específicas em determinada política pública. Os contratos (em sentido amplo) aparecem então como instrumentos regulatórios, permitindo ao Estado a utilização estratégica da contratação pública para alcançar finalidades públicas não necessariamente ligadas às prestações contratuais específicas ${ }^{21}$. Thiago

\section{FREY, 2000.}

21 Dois artigos do professor da Universidade de Coimbra Pedro Gonçalves Costa abordam com propriedade a questão: GONÇALVES, Pedro Costa. 
Lima Breus identifica como finalidades metacontratuais das contratações públicas a possibilidade de que sirvam como instrumento de realização mediata das mais variadas políticas públicas voltadas à prossecução de demandas da sociedade, com suporte no ordenamento jurídico:

Logo, com a inserção de políticas públicas suplementares na contratação pública, ela passa a se consagrar como um instrumento interventivo estatal dirigido (targeted procurement) para produzir resultados mais amplos do que o simples aprovisionamento de bens e serviços necessários à satisfação dos entes estatais. Atualmente, inclusive no Brasil, uma série de iniciativas administrativas e legislativas têm buscado impulsionar cada vez mais a utilização de contratos públicos para a satisfação de objetivos extracontratuais, com destaque à idée-force do desenvolvimento nacional sustentável e sua multidimensionalidade. [...] Como consequência disso, a inserção de finalidades acessórias no âmbito da contratação pública pretende o aproveitamento e, mais, a própria "internalização", na medida das possibilidades jurídicas, sociais e econômicas, das chamadas externalidades positivas (spillover effects) como escopo do próprio contrato. Com a compatibilização entre as finalidades contratuais e as externalidades internalizadas, “o contrato tenderá a fixar relações 'preços-quantidades' que se aproximam do ótimo social" 22 .

Em conclusão parcial deste tópico, convém reconhecer na categoria políticas públicas a existência de elementos e estratégias variadas para o alcance de finalidades públicas, sendo os diversos instrumentos disponíveis juridicamente regulados em diferentes intensidades. Nas diversas etapas que compõem o ciclo das políticas públicas, o planejamento é essencial e regulado normativamente de forma intensa,

A regulação do mercado da contratação pública. Revista de Contratos Públicos - RCP, Belo Horizonte, ano 3, n. 3, p. 2012, 08, mar./ago. 2013; e GONÇALVES, Pedro António P. Costa. Regulação administrativa e contrato. Revista de Direito Público da Economia - RDPE, Belo Horizonte, ano 9, n. 35, jul./set. 2011.

22 BREUS, 2016. 
condicionando inclusive a identificação e escolha - decisão - dentre as várias alternativas existentes. A conclusão não se altera, por evidente, diante da possibilidade de utilização de módulos contratuais convencionais, como contratos de gestão celebrados com organizações sociais.

\section{Planejamento e celebração de contratos de gestão com organizações sociais para presta- ção de serviços de saúde}

Retomando a possibilidade da utilização de arranjos contratuais como uma das possibilidades/instrumentos na operacionalização de políticas públicas, convém anotar que a escolha das alternativas de ação mais adequadas, na fase de elaboração de programas e de decisão, também é uma etapa juridicamente regulada. A Lei de Introdução às Normas do Direito Brasileiro, em seu artigo 20, contém elementos que necessariamente devem integrar o processo de decisão e escolha: a) densificação, à luz do caso concreto, dos valores jurídicos abstratos incidentes; b) consideração das consequências práticas da decisão; c) motivação consistente que demonstre a adequação e necessidade das medidas, inclusive diante de eventuais alternativas ${ }^{23}$. No processo decisório, o planejamento ocupa lugar de destaque e possui regulação jurídico-normativa de intensidade variada, com maior intensidade na sua dimensão financeira-orçamentária.

23 Eis o artigo 20, inserido pela Lei $\mathrm{n}^{\circ}$ 13.655/18: “Art. 20 . Nas esferas administrativa, controladora e judicial, não se decidirá com base em valores jurídicos abstratos sem que sejam consideradas as consequências práticas da decisão. Parágrafo único. A motivação demonstrará a necessidade e a adequação da medida imposta ou da invalidação de ato, contrato, ajuste, processo ou norma administrativa, inclusive em face das possíveis alternativas." 
Nessa etapa preliminar, inicialmente, a necessidade de expansão da cobertura assistencial (nos termos da Lei ${ }^{\circ}$ 8.080/90) deve constar da motivação do ato administrativo que decide pela celebração de qualquer parceria com a iniciativa privada no âmbito dos SUS. Trata-se de reconhecer a imperatividade de estudos técnicos e dados concretos que amparem a decisão jurídico-administrativa de parceria como a alternativa mais adequada.

A celebração de contrato de gestão com organização social para gerenciar e/ou executar atividade pública deve ser precedida de decisão planejada, processualizada e juridicamente fundamentada. Com efeito, apesar de abrir mão da execução direta dos serviços de saúde objeto de contratos de gestão, o Estado mantém responsabilidade de garantir que sejam prestados na quantidade e qualidade apropriados. A relevância do planejamento ${ }^{24}$ se justifica diante da existência

24 Ao identificar a existência de dever constitucional de enunciação de políticas públicas e de formulação de planos em diversas áreas de atuação do Estado, Vanice Valle identifica efeitos deletérios da secundarização da exigibilidade das políticas públicas como instrumento principal de planejamento do agir estatal: “Decorre da formulação da política pública não só o desenho em si das ações a se desenvolverem em resposta a uma agenda previamente definida no momento de identificação dos problemas, mas ainda a estruturação dos meios (inclusive práticas institucionais) necessários ao alcance do resultado cogitado. A par disso, o desenho de políticas públicas, observado o modelo sequencial preconizado pela Administração Pública enquanto ciência autônoma, determina a fixação de metas e indicadores de desempenho que permitam empreender-se, ao final, a indispensável avaliação de seus resultados. A enunciação de políticas públicas determina portanto uma 'antecipação racionalizada e pensada da gestão administrativa futura' e permite a análise da viabilidade técnica, econômica, jurídica, política e social dessa mesma linha de ação cogitada. É nesse plano que se evita a sobreposição de recursos e iniciativas, otimizando os meios que efetivamente se ponham à disposição da Administração, tudo no rumo do cumprimento do dever igualmente constitucional de eficiência". (VALLE, Vanice Regina Lírio do. Réquiem para a ação administrativa planejada: a rutura entre as dimensões executiva e orçamentária. In: BUISSA, L.; REIMANN, Simon (Org.) ; MARTINS, Rafael Lara (Org.) . Direito e Finanças Públicas nos 30 anos da Constituição 
de deveres constitucionais impostos ao Estado, que devem ser executados da forma mais eficiente e eficaz possível, considerando-se os diversos aspectos juridicamente regulados incidentes (em especial, administrativos, orçamentários e financeiros).

Em primeira análise, impõe-se ao gestor público o dever de justificar a opção de realizar determinada atividade por meio da contratação de terceiros (ainda que por meio de ajuste de cooperação), ao invés de executar diretamente as atividades (inclusive com instalações próprias e quadro próprio do Poder Público). Não é demais frisar que a dispensa de certame licitatório (Art. 24, inciso XXIV da Lei n. 8.666/93) aumenta a responsabilidade do gestor em evidenciar a transparência do processo de escolha da entidade parceira (OS) e as razões que conduziram à decisão de execução indireta, ainda que sob forma colaborativa.

Analisando a celebração de contratos de gestão na esfera municipal, Fernando Mânica relembra que o ajuste deve respeitar todos os procedimentos comuns a qualquer contratação, e, especialmente:

- edição de lei municipal sobre organizações sociais e contratos de gestão, contendo os requisitos para qualificação de entidades como organizações sociais, bem como as exigências para celebração, execução e fiscalização dos contratos de gestão; a lei municipal deve respeitar as normas contidas na Lei ${ }^{\circ}$ 9.637/98, bem como o conteúdo da decisão da ADI n 1.923 do STF;

- realização de estudos técnicos e jurídicos acerca das vantagens da parceria, com definição motivada acerca do objeto da avença, dos bens públicos envolvidos, da eventual cessão de servidores públicos, do prazo contratual e dos direitos e deveres das partes envolvidas;

- oitiva do Conselho Municipal de Saúde e outras instâncias

Experiências e desafios nos campos do Direito Tributário e Financeiro. 1. ed. Florianópolis: Tirant lo Blanch (Empório do Direito), 2018. v. 1. p. 319-340). 
como a sociedade civil e os órgãos de controle e fiscalização, com resposta motivada a cada questionamento, crítica ou sugestão apresentados;

- divulgação de edital para qualificação de todas as entidades que preencherem os requisitos legais como organizações sociais no âmbito do município;

- análise do impacto orçamentário da contratação;

- publicação de edital de chamamento público, acompanhado de minuta do contrato de gestão, para escolha da organização social parceira, com observância dos princípios da isonomia, competitividade e vantajosidade;

- celebração e execução de contrato de gestão, com repasse de recursos, acompanhamento e fiscalização permanente, conforme previsto na lei e no instrumento de ajuste, com atuação permanente e contínua do sistema de controle interno e da comissão de avaliação instituída especialmente para esse fim;

- prestação de contas ao Tribunal de Contas ${ }^{25}$.

A questão não tem passado despercebida pelos órgãos de controle externo, em especial pelo Tribunal de Contas da União, notadamente diante do incremento de sua envergadura no texto constitucional ${ }^{26}$. No Acórdão n. 2.057/2016 - Plenário (Processo n. TC 023.410/2016-7), o Tribunal de Contas da União, em resposta à consulta formulada pela

25 MÂNICA, 2017, p.117.

26 “Conscientemente, ou não, a Assembleia Nacional Constituinte imprimiu um novo projeto ao Tribunal de Contas: o exercício da fiscalização operacional. Do extenso estudo empírico realizado por André Rosilho, não se constata qualquer debate substancial sobre fundamentos, limites e conteúdo desta inédita atribuição ao Tribunal de Contas. Um simples silêncio eloquente rompeu com a tradição constitucional de prever tríplice competência fiscalizatória de contas: a "fiscalização contábil, financeira e orçamentária", tal qual o título da Seção IX. Pode-se afirmar que da Constituição de 1988 surge uma nova instituição Tribunal de Contas, tradicionalmente controladora das contas públicas, mas que passou a deter expressa capacidade de controle operacional quanto à legalidade, legitimidade, economicidade, aplicação de subvenções e renúncia de receitas, na condição de auxiliar do Congresso Nacional".(MARQUES NETO, Floriano; PALMA, Juliana Bonacorsi de. Revista Brasileira de Estudos Políticos, Belo Horizonte, n.120, pp. 203-236, jan/jun 2020). 


\section{Comissão de Assuntos Sociais do Senado Federal, expediu as seguintes orientações gerais sobre a celebração de contratos de gestão com OS's:}

(...) 9.2.3. a jurisprudência consolidada do Tribunal de Contas da União (e.g. Acórdãos 3.239/2013 e 352/2016, ambos do Plenário deste Tribunal) é no sentido de reconhecer a possibilidade de realização de contratos de gestão com organizações sociais, com as seguintes orientações sobre a matéria:

9.2.3.1. apesar de abrir mão da execução direta dos serviços de saúde objeto de contratos de gestão, o Poder Público mantém responsabilidade de garantir que sejam prestados na quantidade e qualidade apropriados;

9.2.3.2. do processo de transferência do gerenciamento dos serviços de saúde para organizações sociais deve constar estudo detalhado que contemple a fundamentação da conclusão de que a transferência do gerenciamento para organizações sociais mostra-se a melhor opção, avaliação precisa dos custos do serviço e dos ganhos de eficiência esperados, bem assim planilha detalhada com a estimativa de custos a serem incorridos na execução dos contratos de gestão;

9.2.3.3. a escolha da organização social para celebração de contrato de gestão deve, sempre que possível, ser realizada a partir de chamamento público, devendo constar dos autos do processo administrativo correspondente as razões para sua não realização, se for esse o caso, e os critérios objetivos previamente estabelecidos utilizados na escolha de determinada entidade, a teor do disposto no art. $7^{\circ}$ da Lei 9.637/1998 e no art. $3^{\circ}$ combinado com o art. 116 da Lei 8.666/1993;

9.2.3.4. as organizações sociais submetem-se a regulamento próprio sobre compras e contratação de obras e serviços com emprego de recursos provenientes do Poder Público, observados os princípios da impessoalidade, moralidade e economicidade, sendo necessário, no mínimo, cotação prévia de preços no mercado; 9.2.3.5. não é necessário concurso público para organizações sociais selecionarem empregados que irão atuar nos serviços objeto de contrato de gestão, entretanto, durante o tempo em que mantiverem contrato de gestão com o Poder Público Federal, devem realizar processos seletivos com observância aos princípios constitucionais da impessoalidade, publicidade e moralidade; 
9.2.3.6. os Conselhos de Saúde devem participar das decisões relativas à terceirização dos serviços de saúde e da fiscalização da prestação de contas das organizações sociais, a teor do disposto no art. $1^{\circ}$, §2 ${ }^{\circ}$, da Lei Federal 8.142/1990;

9.2.3.7. os contratos de gestão devem prever metas, com seus respectivos prazos de execução, bem assim indicadores de qualidade e produtividade, em consonância com o art. $7^{\circ}$, I, da Lei 9.637/1998; 9.2.3.8. os indicadores previstos nos contratos de gestão devem possuir os atributos necessários para garantir a efetividade da avaliação dos resultados alcançados, abrangendo as dimensões necessárias à visão ampla acerca do desempenho da organização social;

9.2.3.9. a comissão a quem cabe avaliar os resultados atingidos no contrato de gestão, referida no art. $8^{\circ}$, $\S 2^{\circ}$, da Lei 9.637/1998, deve ser formada por especialistas da área correspondente;

9.2.3.10. devem ser realizados estudos que indiquem qual sistema de remuneração dos serviços prestados é mais adequado para o caso específico do objeto do ajuste a ser celebrado, levando em consideração que a escolha da forma de pagamento por tempo, por procedimentos, por caso, por capitação ou a combinação de diferentes métodos de remuneração possui impacto direto no volume e na qualidade dos serviços prestados à população;

9.2.3.11. os processos de pagamento das entidades contratadas devem estar suportados por documentos que comprovem que os serviços foram efetivamente prestados - demonstrando o controle da frequência dos profissionais, os procedimentos realizados, os pacientes atendidos - e que garantam que os impostos, taxas e encargos trabalhistas aplicáveis ao caso foram devidamente recolhidos;

9.2.3.12. não há amparo legal na contratação de mão de obra por entidade interposta mediante a celebração de termos de compromisso com organizações da sociedade civil de interesse público ou de instrumentos congêneres, tais como convênios, termos de cooperação ou termos de fomento, firmados com entidades sem fins lucrativos;

9.2.3.13. deve ser promovido, no âmbito das unidades federativas, o fortalecimento dos órgãos de controle e de gestão de modo a se permitir o acompanhamento efetivo dos contratos de gestão (grifamos). 
Nos termos da decisão do Supremo Tribunal Federal na já citada ADI 1923-DF, a discricionariedade no procedimento de qualificação (art. $2^{\circ}$, II, da Lei n ${ }^{\circ} 9.637 / 98$ ) deve ser interpretada sob o influxo da principiologia constitucional, em especial dos princípios da impessoalidade, moralidade, publicidade e eficiência. Desta forma, exige-se que o Poder Público conduza procedimento público impessoal, pautado por critérios objetivos, não se admitindo alegações de "mera conveniência" para qualificação e celebração de parcerias com entidades previamente determinadas, sem critério objetivo transparente. Em se tratando de contratação pública, como visto, a desnecessidade de procedimento licitatório em sentido estrito não afasta o dever de abertura de processo administrativo para identificar, objetivamente, as razões de interesse público que indicam a vantagem do regime de parceria com a organização social frente às demais alternativas.

O planejamento necessário passa, no mínimo, por criteriosa verificação comprobatória de que a parceria se mostra mais econômica e eficiente do que a prestação dos mesmos serviços de saúde de forma direta. A relevância e complexidade do planejamento - além dos diversos riscos envolvidos no processo - podem justificar, a depender da realidade local, a contratação de apoio especializado para a estruturação técnico-jurídica de contrato de gestão na área da saúde. Com efeito, caso o ente (Municípios, notadamente) não possua capacidade institucional e expertise técnica para tratar de todos os aspectos complexos ligados à avaliação e eventual mudança do modelo de gestão, ele (o ente) deve buscar a contratação de serviços especializados - não custa relembrar que o contrato de gestão foi concebido justamente com o intuito de permitir o ganho comparativo e eficiência. 


\section{Instrumentos para aferição do ganho de efi- ciência na contratação e serviços públicos de saúde: Value for Money (VfM) X valor público}

Uma etapa de planejamento marcada por imprecisões e vaguezas não permitirá avaliar, em simples palavras, se a gestão por intermédio de organizações sociais trará ou não resultados mais econômicos, eficientes e eficazes para a gestão de determinado serviço público de saúde. É importante notar que o benefício a ser auferido não é encarado sob o prisma prevalente da economicidade - ao contrário, em se tratando de atividade de fomento a entidades da sociedade civil, é necessário perquirir a respeito dos demais benefícios auferidos para as diversas dimensões do interesse público em jogo, sobretudo o ganho de eficiência na prestação dos serviços para a população. Nesse particular, os ajustes colaborativos são celebrados tendo como amparo o interesse minimamente convergente entre os partícipes e decorrem de atividade de fomento desenvolvida pelo Estado. Estas razões, somadas ao fato de o objeto central envolver a gestão de serviço público integrado a política pública para realização de direito fundamental (saúde), indicam que o critério de economicidade que geralmente prevalece para os contratos tradicionais celebrados com empresas (tendo como objeto compras, obras, prestação de serviços comuns, etc) não é o mais adequado para servir como critério decisório a respeito da modalidade de gestão.

Contudo, tanto a Lei $\mathrm{n}^{0} 9.637 / 1998$ como Decreto $\mathrm{n}^{\mathrm{o}}$ 9.190/2017, na esfera federal, disciplinam e qualificam o vínculo entre a União e as OS's por meio de regras vagas no tocante ao planejamento. Em especial, as regras constantes desses diplomas são imprecisas quanto à demonstração, em termos de custo-benefício esperado, da absorção de ativida- 
de pública por organização social em substituição à atuação direta do Estado, considerados impactos esperados a curto, médio e longo prazo.

O Decreto $\mathrm{n}^{\circ}$ 9.190/2017 prevê que o processo de qualificação de entidade privada sem fins lucrativos como organização social compreende as seguintes fases: I - decisão de publicização; II - seleção da entidade privada; III - publicação do ato de qualificação; e IV - celebração do contrato de gestão $\left(\operatorname{art} \cdot 6^{\circ}\right)$. O Decreto possui seção específica que trata da decisão de publicização, ou seja, de transferir a prestação de determinados serviços objeto de execução direta para contratualização mediante celebração de contrato de gestão:

Art. $7^{\circ}$ A proposta de publicização das atividades de que trata o art. $1^{\circ}$ da Lei $n^{\circ} 9.637$, de 1998 , será encaminhada pelo Ministro de Estado supervisor da área ao Ministério do Planejamento, Desenvolvimento e Gestão, devidamente justificada, e explicitará as razões que fundamentam a conveniência e a oportunidade da opção pelo modelo das organizações sociais, observado o disposto no art. $4^{\circ}$ do Decreto ${ }^{\circ}$ 6.944, de 21 de agosto de 2009 .

$\S 1^{\circ}$ A fundamentação de que trata o caput conterá todas as informações pertinentes à tomada de decisão, entre as quais:

I - a descrição das atividades;

II - a análise e a caracterização da comunidade beneficiária das atividades e a definição dos órgãos e das entidades públicos responsáveis pela supervisão e pelo financiamento da organização social;

III - os objetivos em termos de melhoria para o cidadão-cliente na prestação dos serviços com a adoção do modelo de organização social;

IV - a demonstração, em termos do custo-benefício esperado, da absorção da atividade por organização social, em substituição à atuação direta do Estado, considerados os impactos esperados a curto, médio e longo prazo;

$\mathrm{V}$ - as informações sobre cargos, funções, gratificações, recursos orçamentários e físicos que serão desmobilizados, quando a decisão implicar em extinção de órgão, entidade ou unidade administrativa da administração pública federal responsável pelo 
desenvolvimento das atividades;

VI - análise quantitativa e qualitativa dos profissionais atualmente envolvidos com a execução da atividade, com vistas ao aproveitamento em outra atividade ou à cessão para a entidade privada selecionada;

VII - previsão de eventual cessão de imóveis e de outros bens materiais; e

VIII - a estimativa de recursos financeiros para o desenvolvimento da atividade durante o primeiro exercício de vigência do contrato de gestão e para os três exercícios subsequentes.

$\S 2^{\circ}$ A decisão da publicização será efetuada em ato conjunto do Ministro de Estado supervisor e do Ministro de Estado do Planejamento, Desenvolvimento e Gestão, e se for o caso, com anuência da autoridade supervisora, e publicada no Diário Oficial da União. (Destacamos)

A despeito da singeleza do dispositivo, nota-se que a decisão de publicização, que embasa o processo de transferência do gerenciamento dos serviços de saúde para organizações sociais, deve ser precedida de estudo detalhado que contemple a fundada conclusão de que a transferência do gerenciamento para organizações sociais se mostra a melhor escolha administrativa. Dentre outros requisitos, exige-se do gestor público avaliação dos custos do serviço e dos ganhos de eficiência esperados, detalhamento da estimativa de custos a serem incorridos na execução dos contratos de gestão, bens públicos envolvidos, eventual cessão de servidores públicos, prazo contratual e dos direitos e deveres das partes envolvidas. A definição dos prazos contratuais, a propósito, é elemento fundamental desse planejamento, sobretudo diante da ausência de aplicação automática dos prazos contratuais previstos na Lei $\mathrm{n}^{\circ} 8.666 / 93$.

A leitura do dispositivo não permite concluir a respeito da metodologia a ser utilizada para demonstrar, em termos de custo-benefício, as vantagens da absorção da atividade por organização social, considerados os impactos esperados 
a curto, médio e longo prazo. Só será possível aferir se essa expectativa de que as capacidades gerenciais e financeiras do setor privado trarão ganhos efetivos para o Estado de instrumentos adequados de planejamento, a exemplo do Value for Money (VfM) ${ }^{27}$, forem utilizados.

Ao se referirem ao value for money como combinação entre economia, eficácia e eficiência ${ }^{28}$, anotam Carlos Oliveira Cruz e Joaquim Miranda Sarmento:

OVfMé uma medida da utilidade do dinheiro gasto. Essa definição é diferente de "a solução mais barata". Maximizar o VfMé procurar a máxima eficiência. Como a Comissão de Auditoria do Reino Unido afirma, "Simplificando, o VfM significa obter o benefício máximo com os recursos disponíveis" (Audit Commission, 2003). Essa é uma decisão tomada por agentes económicos e amplamente estudada pela teoria da decisão (por exemplo, Schoemaker, 1982; Anand, 1993). Maximizar o VfM precisa levar em conta os conceitos de eficiência (para garantir baixos custos) e eficácia (para alcançar o objetivo/utilidade). [...] O VfM é diretamente proporcional à utilidade e inversamente proporcional ao custo. O VfM consiste na utilidade retirada de cada compra ou gasto público (Ball et al., 2007). Tal, como referido, baseia-se não no menor custo de aquisição/produção, mas na máxima eficiência dos gastos públicos, isto é, ponderando custo e qualidade. Isso significa que, quando se opta por realizar um investimento público através de uma PPP, procura-se maximizar a utilidade dos dinheiros públicos" 29 .

\section{LEONARDO, 2018.}

28 "Economia significa minimizar o custo dos recursos utilizados numa atividade mantendo a quantidade e qualidade desejada. Eficácia significa a extensão em que os objetivos foram cumpridos e a relação entre o impacto previsto e o impacto real de uma dada atividade. Eficiência significa a relação entre resultados e os recursos empregados. A eficiência pode ser vista de duas formas: o mínimo de inputs para um determinado nível de outputs ou então o máximo de outputs para um determinado nível de inputs. Por regra, numa PPP, e como decorre do exemplo anterior, a eficiência, em termos de VfM, mede-se pela primeira forma" (CRUZ, Carlos OLIVEIRA, SARMENTO, Joaquim Miranda. Manual de Parcerias Público-Privadas e concessões. Belo Horizonte: Fórum, 2020, p. 177).

29 ID. P.178 
Em síntese, o termo Value for Money (VfM) é usado para avaliar se uma determinada organização obteve ou não o máximo de benefício dos bens e serviços contratados e fornecidos com os recursos disponíveis para tal. Em contratações administrativas (em sentido amplo), a literatura nacional tem dedicado espaço ao VfM na análise das etapas preparatórias à celebração de parcerias público-privadas ( $P P P s)$, nas modalidades concessão patrocinada e concessão administrativa. Após a realização do Value for Money é analisado o Comparativo do Setor Público (CSP) ${ }^{30}$, isto é, o custo da prestação do mesmo serviço diretamente pelo Estado ou por entidades da Administração Indireta ${ }^{31}$.

30 A respeito de Value for Money nas PPPs e as dificuldades de estabelecer a comparação com o setor público: "Em geral, esta análise implica na construção de um Projeto Público de Comparação (ou Public Sector Comparator - PSC), onde se levantam o custo provável da prestação do serviço pela Administração Pública, que em seguida é comparado ao modelo de gestão privada via PPP. No modelo público, muitas vezes são necessárias adaptações para que sejam considerados todos os gastos com investimentos e despesas operacionais, riscos, tributos e seguros a fim de se manter a comparabilidade das duas abordagens. Esta modelagem financeira permite avaliar se há vantagem econômica para o Estado ao se contratar uma PPP. Yescombe (2007) assinala a dificuldade da construção do PSC no estabelecimento de parâmetros comparáveis dos custos públicos com aqueles de uma gestão privada. A taxa de desconto a ser utilizada no cálculo do valor presente, os ajustes de transferência de risco e ajustes do tratamento fiscal são exemplos de fragilidades que o método está exposto. A ausência de um quadro metodológico transparente e detalhado para o cálculo do PSC torna este instrumento de avaliação financeira vulnerável a um enviesamento da análise do mérito da decisão a favor de uma PPP" (BUCCINI, A. R. A. ; PAIVA, D. A. ; ALMEIDA, T. F. . Value for Money: as PPPs trazem eficiência? Uma análise do projeto das Unidades de Atendimento Integrado do Governo de Minas Gerais. 2015. Trabalho apresentado no VIII Congresso CONSAD de Gestão Pública. Disponível em: http://www.sgc.goias.gov.br/upload/arquivos/2016-10/value-formoney-as-ppps-trazem-eficiEncia-uma-anAlise-do-projeto-das-unidadesde-atendimento-integrado-do-governo-de-minas-gerais.pdf. Acesso em: 03 mar. 2020.

31 O Guia Suplementar para Avaliações de Value For Money da Prefeitura do 


\section{Egon Bockmann Moreira ressalta a importância da es- colha da modelagem contratual mais adequada em tempos de escassez e crise fiscal:}

Ou seja, o que está em jogo não é apenas o Value for Money - VfM do empreendimento (a comparação entre custos e pagamentos em várias modelagens de contratação (empreitada de obras, concessão comum, PPP etc.), levando-se em conta o ciclo de vida e a qualidade), mas a primazia daqueles que não impactem, de modo significativo e em curto prazo, no orçamento público. Afinal, dentre os tipos contratuais, um precisa ser selecionado pelo Estado. A escolha não pode ser aleatória, em vista do que se pretende com tal contrato (a utilidade pública). O que se torna sensível em Estados com escassez de verbas públicas a experimentar a crise permanente. Nestes casos, a definição de quem realizará o aporte de recursos acaba por se tornar uma das questões de fundo mais importantes. Se a alocação do orçamento exigir o gasto em outros projetos/setores, isso tende a afetar o que aqui vou apelidar de Value for Public Money - VfPM e a inibir soluções que demandem gasto intenso de verbas públicas. A obra pode ser maravilhosa e duradoura, mas talvez não seja o caso de ser bancada por verbas orçamentárias. Se o dinheiro público estiver orientado à saúde e educação, não há valor algum na alternativa que o redirecione para metrôs e duplicação de estradas. Isso necessita ser pesado quando da escolha pública. A análise do VfM em situações de extrema escassez de recursos estatais inibe certas opções e incentiva outras, que não envolvam desembolso de verbas públicas ${ }^{32}$.

Município do Rio de Janeiro, por exemplo, informa que uma das atividades a serem realizadas antes da implementação de uma PPP/concessão deve ser o desenvolvimento da análise de VFM, com o objetivo de comparar, em termos quantitativos, se faz sentido desenvolver o projeto na forma de uma PPP/concessão ou através de um processo tradicional de aquisição pública. Desta forma, o referido guia recomenda o desenvolvimento da análise de VFM ao menos em duas fases distintas do processo, quais sejam: a) ex-ante, na fase de avaliação do projeto; b) ex-post, uma vez que o projeto tenha sido adjudicado para o vencedor da licitação. Disponível em: http://www.rio.rj.gov.br/dlstatic/10112/5305003/4138533/ GuiaSuplementarparaAvaliacoesdeValueforMoney.pdf. Acesso em: 14 nov. 2019.

MOREIRA, 2018. 
O mesmo raciocínio se aplica para a mudança do modelo de gestão de equipamentos e serviços públicos. O ente público deve proceder detalhada avaliação, construindo o Value for Money para demonstrar se os custos, pagamentos e riscos (dentre outros elementos) justificam o novo modelo. É necessário desenvolver, no mínimo, projeções financeiras distintas para comparação, sendo uma delas o (1) comparativo do setor público (CSP), simulando os custos envolvidos na gestão direta pelo ente e outra (2) o modelo de custos da gestão por meio da organização social, com os pagamentos estimados pelo ente para a entidade para gerir os mesmos equipamentos e serviços considerados no item anterior. Somente a comparação entre as duas projeções fornecerá elementos seguros para amparar decisão a respeito do modelo mais adequado quanto à economicidade, à eficácia e à eficiência. De qualquer maneira, a realização dos estudos preliminares não afasta a necessidade de acompanhamento, mensuração e avaliação durante e após a execução do contrato de gestão, sobretudo em razão do impositivo controle de resultados necessário para a execução financeira do ajuste (com cláusulas de remuneração atreladas ao desempenho) e também para a eficácia da política pública subjacente.

Certamente as projeções não seguirão a mesma metodologia para os comparativos se se tratar da transferência da gestão de um serviço público já em funcionamento por gestão direta (por exemplo, gestão de um hospital público que atualmente funciona - ou já funcionou - por meio de gestão direta) ou da gestão de um serviço público criado e ainda sem histórico de gestão estatal (gestão inicial de um novo hospital público). Também não há cabimento em se exigir a mesma estrutura demonstrativa de custos presentes na Lei $n^{\circ} 8.666 / 93$, por exemplo, em razão da diversidade dos objetos e objetivos contratuais. 
É verdade que é discutível se o Value for Money constitui metodologia adequada e/ou suficiente para aplicação na gestão da saúde pública, notadamente em razão da existência de diversos valores não econômicos envolvidos (melhorar a qualidade de vida da população, por exemplo). Ernesto Faria, Lívia de Souza e Maria Ligia Saad ${ }^{33}$, por exemplo, analisam a experiência do Reino Unido na aplicação do VfM na área da saúde para questionar o que é ou não é medido e como valorar os resultados dos serviços oferecidos aos cidadãos. Com fundamento na teoria do valor público, nos moldes propostos por Mark Moore, ressaltam a importância de se avaliar, além dos resultados, os meios utilizados para chegar a eles, bem como a confiança e a legitimidade na execução das ações de saúde pública, sem olvidar de assuntos como equidade, ethos e accountability.

Humberto Martins e Caio Marini, ao analisarem modelos de gestão para resultados, resumem a concepção de valor público proposta por Mark Moore na criação de estratégias voltadas à busca de respostas efetivas baseadas no chamado triângulo estratégico composto por três processos: gestão da estratégia (a estratégia deve ser substantivamente valiosa, gerando produtos a baixo custo em termos de dinheiro e autoridade); gestão política (deve ser legítima e politicamente sustentável) e gestão da eficiência (a estratégia precisa ser operacional e administrativamente factível $)^{34}$. Os três processos do triângulo, traduzidos por Faria, Souza eSaad como definição de propósitos, ambiente autorizador e construção de capacidade operacional, amparam o entendimento subjacente de que o valor público exige foco não apenas nos recursos empregados e produtos gerados como também nos processos utilizados e nos impactos (diretos e indiretos) gerados para a socieda-

33 FARIA, SOUZA e SAAD, 2015.

34 MARTINS e MARINI, 2010, p.51 
$\mathrm{de}^{35}$. A metodologia enfoca o valor criado para os cidadãos, não somente em sua dimensão econômico-financeira. Essa a razão da conclusão proposta pelos autores, segundo a qual:

[...] medidas de custo-benefício podem não ser suficientes para a avaliação da provisão de serviços públicos na área da saúde. Ainda que eficácia e eficiência sejam resultados importantes a serem atingidos - especialmente em um cenário de limitação de gastos e custos crescentes - é necessário considerar variáveis mais abrangentes que permitam legitimar e dar suporte às escolhas estratégicas feitas pelo governo no sentido de garantir benefícios em curto, médio e longo prazo para a sociedade. Assim, [...] a abordagem do valor público pode contribuir para a avaliação da prestação de serviços públicos, já que permite agregar variáveis subjetivas, como expectativas, satisfação e confiança, às variáveis mais objetivas, relacionadas ao desempenho. Adotar uma abordagem de geração de valor público implica que tanto as escolhas na prestação de serviços públicos, quanto o acompanhamento na provisão dos mesmos, devem se pautar pelos benefícios gerados ao cidadão, de acordo com o que este considera valor. Uma vez cumprida a etapa da eficiência alocativa, faz-se fundamental garantir o atendimento público de saúde com foco nos resultados identificados como prioritários, assegurando a efetividade das ações. Apenas articulando a adequada alocação de recursos com a eficiência na produção de serviços, é possível garantir que o atendimento público de saúde se transforme em benefícios reais para a população, cumprindo com efetiva geração de valor público ${ }^{36}$.

Os propósitos e limites do artigo não trazem discussão relativa a qual abordagem é mais adequada, Value for Money ou valor público, tampouco se são compatíveis. Trata-se, ao contrário, de enxergar a decisão relativa à forma de gestão de determinado serviço público de saúde (em particular, no tocante à celebração ou não de contratos de gestão com organizações sociais) como juridicamente integrante de processo de planejamento de políticas públicas. Desta forma, é necessário

35 Id. P.47

36 FARIA, SOUZA e SAAD, 2015, p.77 
rigoroso processo de avaliação preliminar para identificar qual o modelo mais adequado para provisão, à sociedade, de um serviço público eficiente e eficaz. O planejamento e a escolha de uma metodologia de forma consciente e tecnicamente motivada são imperiosos para permitir a avaliação das vantagens no repasse da gestão para organizações sociais, em detrimento da gestão direta e de outras modalidades de gestão.

\section{É importante ressaltar a essencialidade da análise inicial e de suas etapas para o êxito e o aprendizado em políticas públicas:}

Na análise ex ante, partindo-se da identificação e caracterização de um problema que demandaria intervenção do Estado, é necessário que sejam estabelecidos objetivos claros para a ação governamental, bem como um desenho que efetivamente permita alcançá-los, considerando, por exemplo, os incentivos dos agentes envolvidos. Antes de implementar a ação governamental, precisa-se estimar os custos e os benefícios esperados, ainda que essa análise possa ser ponderada por fatores de difícil mensuração. Essa relação de custo-benefício deve ser apresentada aos tomadores de decisão e estar transparente para a sociedade como um todo. A qualidade das informações obtidas e das decisões tomadas na análise ex ante afeta sobremaneira o desenvolvimento do ciclo da política pública, afetando o nível de desenvolvimento e a qualidade da política pública executada. Independentemente da qualidade da análise e do planejamento realizado, na execução da política pública, deve-se monitorar e avaliar a intervenção para garantir que sejam alcançados os impactos esperados sobre o problema identificado. É importante que o monitoramento, a avaliação e o controle posteriores sejam elaborados e planejados antes da implementação da política pública, com a definição de quais indicadores e ações serão necessários, quem serão os responsáveis e quando e como essas ações serão desenvolvidas e seus resultados comunicados. Muitas políticas públicas são de difícil avaliação, ou, em muitos casos, sua execução é cara, pois os dados necessários não foram planejados e coletados ou não está definido a quem caberá essa avaliação ${ }^{37}$.

37 Avaliação de políticas públicas: guia prático de análise ex ante, volume 1./ 
A necessidade de planejamento detalhado para aferição de custos e benefícios foi objeto de atenção da Estratégia Nacional de Combate à Corrupção e à Lavagem de Dinheiro (ENCCLA). Por meio da Ação n ${ }^{0} 3 / 2018$, a ENCCLA elaborou diagnóstico e propôs medidas visando fortalecer o combate às fraudes nos contratos de gestão da saúde pública. Dentre as recomendações apresentadas, destacamos:

[...]h) Deverá a Administração demonstrar o quanto de recursos públicos é investido atualmente na saúde pública versus o quanto se gastará com o pagamento de Organização Social versus o quanto se gastará para arcar com o custo do remanescente, inclusive da demanda reprimida;

i) Que a demonstração dos custos envolvidos na prestação dos serviços é indispensável à comprovação da economicidade da sistemática, ou seja, é imprescindível que se demonstre que a atividade realizada pela Organização Social irá gerar um dispêndio menor de verbas públicas, bem como possibilitará prestação do serviço público com mais eficiência;

j) Que deve ser demonstrada previamente a vantajosidade econômica, para o Poder Público, do processo de fomento ao Terceiro Setor, só se justificando a prestação de serviços pelas Organizações Sociais quando, comprovadamente, esta se revelar mais econômica do que a execução direta. ${ }^{38}$

Em síntese, a ausência de metodologia consistentemente motivada para aferir os ganhos de eficiência com a mudança do modelo de gestão caracteriza planejamento deficiente, apto a acarretar a aplicação de sanções aos gestores responsáveis. É preciso planejar e demonstrar, de forma fundamentada,

Casa Civil da Presidência da República, Instituto de Pesquisa Econômica Aplicada. - Brasília : Ipea, 2018.

38 Diagnóstico - Ação 3/2018 - ENCCLA. Diagnóstico e proposição de medidas visando a fortalecer o combate às fraudes nos contratos de gestão da saúde pública, com enfoque particular em face de Organização Sociais - OSs em Saúde. Disponível em: http://enccla.camara.leg.br/acoes/ ENCCLA2018Ao03Diagnstico.pdf. Acesso em: 03 dez. 2019. 
que a celebração de contrato de gestão é a opção mais adequada para a gestão do serviço público específico.

Compete, portanto, ao ente público optar conscientemente pela metodologia que possa proteger o Erário e valorizar a prestação dos serviços públicos de saúde, considerando, também a participação da comunidade na gestão do Sistema Único de Saúde, conforme prevê a Lei no 8.142/90, que estabelece:

Art. $1^{\circ}$ O Sistema Único de Saúde (SUS), de que trata a Lei ${ }^{\circ}$ 8.080/90, contará em cada esfera de governo, sem prejuízo das funções do Poder Legislativo, com as seguintes instâncias colegiadas: I- a Conferência de Saúde; e

II- o Conselho de Saúde.

$\S 1^{\circ}$ A Conferência de Saúde reunir-se-á a cada quatro anos com a representação de vários seguimentos sociais para avaliar a situação de saúde e propor as diretrizes para a formulação da política de saúde na instância correspondente, inclusive nos aspectos econômicos e financeiros, cujas decisões serão homologadas pelo chefe de poder legalmente constituído em cada esfera de governo. $\S 2^{\circ} \mathrm{O}$ Conselho de Saúde, em caráter permanente e deliberativo, órgão colegiado composto por representantes do governo, prestadores de serviço, profissionais de saúde e usuários, atua na formulação de estratégias e no controle da execução de política de saúde na instância correspondente, inclusive nos aspectos econômicos e financeiros, cujas decisões serão homologadas pelo chefe do poder legalmente constituído em cada esfera de governo. (Grifamos)

Dessa forma, a eleição da metodologia adequada pelo gestor e a oitiva das instâncias colegiadas de saúde (como o Conselho Municipal de Saúde, no âmbito dos Municípios) são medidas necessárias que, além disso, colaborarão com a decisão político-administrativa da publicização contratual sob os aspectos da legalidade (em sentido amplo) e legitimidade, em atendimento ao princípio democrático. 


\section{Conclusão}

A consideração do contrato de gestão como instrumento ou ferramenta componente das políticas públicas de saúde insere no debate a complexidade da abordagem de direito e políticas públicas. A abordagem permite partir do regime jurídico-constitucional da saúde pública para considerar a decisão de publicização como finalisticamente orientada e integrada às políticas públicas, a despeito da existência de normas específicas relativas ao regime jurídico dos contratos de gestão.

O artigo tratou da necessidade de planejamento prévio para escolha modelo jurídico do contrato gestão para prestação de serviços públicos de saúde. O estudo permitiu concluir que o ordenamento jurídico (Lei $\mathrm{n}^{\circ}$ 9.637/1998 e o Decreto $n^{\circ} 9.190 / 2017$, na esfera federal), muito embora exija o planejamento, não possui densidade normativa suficiente no que se refere à forma da demonstração pelo Poder Público do custo-benefício da absorção da atividade por organização social, em substituição à atuação direta do Estado. Em igual medida, a necessidade de instrumentos objetivos de avaliação - previamente definíveis - é imposta diante da conformação jurídico-normativa do contrato de gestão como instrumento vocacionado ao incremento da eficiência e eficácia. Essas constatações amparam ainda a conclusão de que a decisão referente à publicização - para utilizar expressão consagrada pelo Plano Diretor da Reforma do Estado - é juridicamente vinculada à realização de etapa prévia de planejamento para que as finalidades de interesse público que secundaram a decisão possam ser minimamente monitoradas e controladas.

O estudo ampara a conclusão de que existe vinculação procedimental da etapa de planejamento - ou seja, dever de 
realizá-lo - mas não do instrumento ou abordagem específica. A escolha tecnicamente motivada por determinada abordagem ou instrumento - como Value for Money ou valor público - deverá ser conduzida pelo ente político competente, de acordo com as peculiaridades do serviço público específico e finalisticamente orientada para a identificação do modelo mais adequado para provisão, à sociedade, de um serviço público eficiente e eficaz. Desta forma, compete ao ente público, na fase da decisão de publicização, optar conscientemente pela metodologia que possa proteger o Erário e valorizar a prestação dos serviços públicos de saúde, considerando também a participação da comunidade na gestão do Sistema Único de Saúde.

\section{Referências}

BREUS, Thiago Lima. A realização de finalidades acessórias, transversais e/ou horizontais na contratação pública contemporânea. Revista de Contratos Públicos - RCP, Belo Horizonte, ano 5, n. 8, p. 173-196, set./fev. 2016.

BUCCI, Maria Paula Dallari. O conceito de política pública em direito. In Políticas Públicas: Reflexões sobre o Conceito Jurídico (Maria Paula Dallari Bucci, org.) São Paulo: Saraiva, 2006, pp. 1-50.

BUCCI, Maria Paula Dallari; COUTINHO, Diogo Rosenthal. Arranjos jurídico-institucionais da política de inovação tecnológica: uma análise baseada na abordagem de direito e políticas públicas. In: Inovação no Brasil : avanços e desafios jurídicos e institucionais[S.l: s.n.], p. 339 : il. ; 24 cm, 2017.

CRUZ, Carlos OLIVEIRA, SARMENTO, Joaquim Miranda. Manual de Parcerias Público-Privadas e concessões, Belo Horizonte: Fórum, 2020, p. 177. 
ESTRATÉGIA NACIONAL DE COMBATE À CORRUPÇÃO E LAVAGEM DE DINHEIRO. Diagnóstico - Ação 3/2018 - ENCCLA. Diagnóstico e proposição de medidas visando a fortalecer o combate às fraudes nos contratos de gestão da saúde pública, com enfoque particular em face de Organização Sociais - OSs em Saúde. Disponível em: http:/ / enccla.camara.leg.br/acoes/ENCCLA2018Ao03Diagnstico.pdf. Acesso em: 27 nov. 2019.

FARIA, Ernesto Martins de; SOUZA, Lívia Magro de e SAAD, Mária Lígia M. Value-for-money e geração de valor público na atuação das organizações sociais de saúde: contribuições para o governo do estado de São Paulo. Dissertação de Mestrado defendida na Escola de Administração de Empresas da Fundação Getúlio Vargas, SP. Disponível em: https:/ / bibliotecadigital.fgv.br/dspace/ handle/10438/14166. Acesso em: 22.11.2019.

FREY, Klaus. Políticas Públicas: um debate conceitual e reflexões referentes à prática da análise de políticas públicas no brasil. Planejamento e Políticas Públicas, Brasília, n. 21, p. 211-259, 2000.

GABARDO, Emerson; REZENDE, Maurício Corrêa de Moura. $\mathrm{O}$ conceito de interesse público no direito administrativo brasileiro. Revista Brasileira de Estudos Políticos, Belo Horizonte, n. 115, pp. 267-318, jul./dez. 2017.

INSTITUTO DE PESQUISA ECONÔMICA APLICADAS - IPEA. Avaliação de políticas públicas: guia prático de análise ex ante, volume 1 / Casa Civil da Presidência da República, Instituto de Pesquisa Econômica Aplicada. Brasília: Ipea, 2018.

LEONARDO, Vera Sirlene et al. Publicização no Setor Público: indicadores econômicos e financeiros em organização 
social de educação. Revista Unifamma, vol. 17, 2018: Disponível em: http://revista.famma.br/unifamma/index. php/RevUNIFAMMA/article/view/430. Acesso em: 14 nov. 2019.

MÂNICA, Fernando Borges. Prestação de serviços de assistência à saúde pelos municípios. Belo Horizonte: Fórum, 2017.

MARQUES NETO, Floriano; PALMA, Juliana Bonacorsi de. Revista Brasileira de Estudos Políticos, Belo Horizonte, n.120, pp. 203-236, jan/jun 2020.

MARTINS, Humberto Falcão; MARINI, Caio. Guia de Governança para resultados na Administração Pública. Brasília: Publix, 2010, p.51. Disponível em: http:/ / bvsms. saude.gov.br/bvs/publicacoes/guia_governanca_resultados_administracao_publica.pdf. Acesso em: 03 mar. 2020.

MARTINS, Rafael Lara (Org.). Direito e Finanças Públicas nos 30 anos da Constituição Experiências e desafios nos campos do Direito Tributário e Financeiro. 1. ed. Florianópolis: Tirant Blanch (Empório do Direito), 2018. v. 1. p. 319-340

MINISTÉRIO PÚBLICO DE CONTAS DO TRIBUNAL DE CONTAS DOS MUNICÍPIOS DO ESTADO DE GOIÁS. Recomendação Conjunta ${ }^{0}$ 01/2019 MCP/MPE/MPF/MPT. Disponível em: Disponível em: https://www.tcm.go.gov. $\mathrm{br} / \mathrm{mpc} / 2019 / 04 / 17 /$ ministerios-publicos-recomendam-ao-municipio-de-aparecida-de-goiania-diretrizes-para-a-transferencia-da-gestao-de-servicos-de-saude-a-organizacoes-sociais/. Acesso em: 12 nov. 2019.

MOTTA, Fabrício. Organizações sociais e a Lei n ${ }^{0}$ 13.019/14. In: MOTTA, Fabrício; MÂNICA, Fernando Borges; OLIVEIRA, Rafael Arruda. (Org.). Parcerias com o terceiro setor: as 
inovações da Lei $\mathrm{n}^{\mathrm{0}}$ 13.019/14. 2ed.Belo Horizonte: Fórum, 2018, p. 157-179

OLIVEIRA, Rafael Arruda. A celebração de contratos de gestão com organizações sociais e os limites de aplicação da Lei Federal no 8.666/93. Fórum de Contratação e Gestão Pública - FCGP, Belo Horizonte, ano 12, n. 144, p. 56-67, dez. 2013.

PEREIRA, Luiz Carlos Bresser. A reforma do estado nos anos 90: lógica e mecanismos de controle. Brasília: Ministério da Administração Federal e Reforma do Estado, 1997, 58 p. (Cadernos MARE da reforma do Estado, v. 1).

REIS, Luciano Elias; BLANCHET, Luiz Alberto. Margem de preferência para microempresas e empresas de pequeno porte local e regional: uma estratégia de regulação estatal desenvolvimentista. Revista Brasileira de Estudos Políticos, Belo Horizonte, n. 117, pp. 275-320, jul./dez. 2018.

RIO DE JANEIRO. Guia Suplementar para Avaliações de Value For Money da Prefeitura do Município do Rio de Janeiro. Disponível em: Disponível em: http://www.rio. rj.gov.br/dlstatic/10112/5305003/4138533/GuiaSuplementarparaAvaliacoesdeValueforMoney.pdf. Acesso em: 14 nov. 2019.

VALLE, Vanice Regina Lírio do. Réquiem para a ação administrativa planejada: a rutura entre as dimensões executiva e orçamentária. In: BUISSA, L.; REIMANN, Simon (Org.); 
Concepção e desenho da pesquisa realizadas pelo coautor Fabrício Motta como iniciativa integrante do Projeto de Pesquisa "Finanças e políticas públicas: análises, planejamento e controle no contexto do federalismo cooperativo". Coleta e processamento dos dados de pesquisa realizadas pela coautora Fernanda de Moura Ribeiro Naves. Análise e interpretação dos dados foram etapas realizadas conjuntamente pelos dois coautores, discutindo a evolução da jurisprudência à luz de casos concretos apreciados na atividade profissional de ambos no Tribunal de Contas dos Municípios de Goiás. Os coautores trabalharam conjuntamente na elaboração do texto definitivo, cuja revisão final ficou a cargo do coautor Fabrício Motta. (Texto informado pelos autores)

Recebido em 16/03/2020

Aprovado em 24/06/2020

Fabrício Macedo Motta

E-mail: fabriciommotta@gmail.com

Fernanda de Moura Ribeiro Naves

E-mail: fernanda.naves@tcm.go.gov.br 